\title{
UJI POTENSI ANTIJAMUR CANDIDA ALBICANS EKSTRAK DAUN GELINGGANG (CASSIA ALATA L.) DIBANDINGKAN DENGAN SEDIAAN DAUN SIRIH YANG BEREDAR DI PASARAN SECARA IN VITRO
}

\author{
Yustini Alioes*, Amalia Kartika, Eriza Amalia Zain, Vanesha Azzura \\ Departemen Biokimia Fakultas Kedokteran Universitas Andalas, Padang \\ *e-mail: yustinialioes14@gmail.com
}

Received 20 October 2018

Accepted 20 December 2018

\begin{abstract}
Abstrak
Candida albicans merupakan salah satu contoh mikroorganisme patogenik penyebab infeksi pada bagian lumen organ tubuh manusia yang berbentuk saluran. Candida albicans pada saluran reproduksi dan saluran urinaria wanita sering dikenal dengan "penyakit keputihan". Salah satu cara mengatasi munculnya keputihan adalah dengan membersihkan daerah kewanitaan menggunakan larutan antiseptik seperti povidone iodine. Masyarakat pada umumnya juga menggunakan sediaan daun sirih yang telah beredar di pasaran. Sediaan ini juga dikenal sebagai antiseptik sehingga dapat menghambat pertumbuhan C. Albicans, selain daun sirih (Piper bitle L.), ternyata daun gelinggang atau ketepeng cina (Cassia alata L.) juga memiliki aktivitas antibakteri dan antijamur. Penelitian ini merupakan penelitian eksperimental dengan menggunakan isolat jamur C.albicans. Proses ekstraksi daun gelinggang dilakukan dengan teknik maserasi menggunakan pelarut metanol, alkohol 96\%, dietil eter, dan infusa. Ekstrak dan SDS diuji aktivitas antijamurnya dengan menggunakan metode difusi agar menggunakan kertas cakram. Analisis uji ini dilakukan dengan mengukur zona hambatan ekstrak dan sediaan daun sirih terhadap pertumbuhan jamur. Analisis nilai persentase aktivitas zona hambat ekstrak metanol daun C.alata menunjukkan tidak adanya perbedaan yang signifikan dengan SDS 1 (asymp. Sig. $=0,245)$ dan dengan SDS 2 (asymp. Sig. = 0,882) dalam menghambat pertumbuhan jamur C.albicans. Ekstrak metanol daun gelinggang memiliki efektifitas yang hampir sama dengan dua kelompok perlakuan SDS yang beredar di pasaran (SDS 1 dan SDS 2).
\end{abstract}

Kata kunci: Antijamur, Candida albicans, sediaan daun sirih (SDS), ekstrak daun Gelinggang (Cassia alata L.).

\begin{abstract}
Candida albicans is one of pathogenic microorganisms that cause infections in the lumen of the organs of human body in the shape of the channel. Candida albicans in the reproductive tract and women urunaria tract is often known as "diseases of vaginal discharge". One way of overcoming the appearance of vaginal discharge is to clean the area using an antiseptic solution of femininity such as povidone iodine. Society in General also use material of betel leaf that has been circulating in the market. This material is also known as an antiseptic so that it can inhibit the growth of C. albicans. In addition to the betel leaf (Piper bitle 1.), turns the leaves gelinggang or Chinese ketepeng (Cassia alata L.) also has antibacterial and antifungal activity. The objective of this study was to compare the test potential antifungal Candida albicans gelinggang leaves (Cassia alata L.) with material of betel leaf that already circulating in the market (SDS). This research is experimental research using fungal isolates of C. albicans. The extraction process of leaf gelinggang done with the technique of maceration using methanol solvent, $96 \%$ alcohol, diethyl ether, and infusa. Extract and SDS tested of antifungal activity by using diffusion method using paper discs. The analysis of
\end{abstract}


the test is done by measuring the resistance zone extracts and preparations betel leaf against mold growth. The analysis of the value of the percentage of the activity of the methanol extracts of the leaves of the inhibitory zones c. alata indicates the absence of a significant difference with the SDS 1 (asymp. Sig. = 0.245) and with SDS 2 (asymp. Sig. = 0.882) in inhibiting the growth of c. albicans yeast.The methanol extract of gelinggang leaves treatment has effectiveness similar to the treatment of the two groups of SDS (SDS 1 and SDS 2) that is circulating in the market.

Keywords: Antifungal preparations, Candida albicans, Betel leaf (SDS), Gelinggang leaf extract (Cassia alata L.).

\section{Pendahuluan}

Candida adalah jamur golongan khamir yang paling umum ditemukan di rongga mulut, saluran pencernaan, saluran reproduksi dan kulit khususnya spesies Candida albicans.Candida albicans (C.albicans) merupakan salah satu organisme penyebab masalah kesehatan reproduksi pada wanita, yaitu flour albus.Flour albus (keputihan) atau keluarnya cairan berlebihan dari genitalia eksterna merupakan hal yang dikeluhkan banyak wanita (Hawkins, 2011; Zubier et $a l$, 2010). Bila ditinjau dari penyebabnya, maka keputihan dibedakan menjadi keputihan fisiologis dan keputihan patologis (Berek dan Berek, 2007). Infeksi mukoda vagina oleh Candida menjadi penyebab umum dari keputihan dimana menurut penelitian menunjukkan sebanyak $75 \%$ wanita di dunia pernah mengalami satu kali kandidiasis vaginalis sepanjang hidupnya dan $45 \%$ diantaranya mengalami dua kali atau lebih (Hawkins, 2011; Zubier et al, 2010).

Salah satu cara mengatasi munculnya keputihan adalah dengan membersihkan daerah kewanitaan menggunakan larutan antiseptik seperti povidone iodine. Pemakaian larutan antiseptik bukanlah hal yang baru karena sebagian besar wanita menganggap larutan antiseptik adalah cara untuk membersihkan daerah kewanitaan saat mereka mengalami keputihan. Selain penggunaan larutan antiseptik sebagian besar wanita juga menggunakan sediaan daun sirih (SDS) yang telah beredar di pasaran. Sediaan tersebut dikenal dapat berfungsi sebagai antiseptik (bakterisida dan fungisida) yang bermanfaat untuk menghambat pertumbuhan mikroorganisme penyebab keputihan, seperti C. albicans. Produksi berbagai macam sediaan yang berbahan baku daun sirih didasari dari kemampuan daun sirih dalam mengobati keputihan (Wijayanti et al, 2011).

Pemanfaatan sumber obat dari alam sanagt memungkinkan di Indonesia yang kaya akan berbagai sumber flora. Pemakaian bahan alam ini dalam upaya penemuan antijamur yang baru dan lebih efektif melawan infeksi. Selain daun sirih (Piper bitle L.), ternyata daun gelinggang atau ketepeng cina (Cassia alata L.) memiliki aktivitas antibakteri dan antijamur. Hal ini disebabkan karena adanya kandungan zat kimia yang terdapat dalam tumbuhan tersebut. Daun tumbuhan gelinggang mengandung sejumlah turunan antraquinon, seperti aloe-emodina, asam krisofanat, asam isokrisofanat, rein, alkaloida, dan sitosterol (Syamsuhidayat dan Ria, 1991)

Oleh karena itu, penulis tertarik untuk melakukan penelitian mengenai perbandingan ekstrak daun gelinggang dan sediaan daun sirih yang beredar di pasaran terhadap daya hambat $C$. albicans dengan melakukan analisis eksperimental pada isolat jamur C. albicans.

\section{Metode Penelitian}

Penelitian ini dilakukan selama 4 bulan di Laboratorium Biokimia dan Mikrobiologi Fakultas Kedokteran Universitas Andalas. Penelitian ini 
merupakan penelitian eksperimental dengan menggunakan isolat jamur C.albicans yang didapat dari Laboratorium Mikrobiologi Fakultas Kedokteran Universitas Andalas. Bahan yang digunakan dalam penelitian adalah daun gelinggang (Cassia alata. L) diambil di daerah sekitar RT 3 RW 5 Kelurah Sawahan Timur Kota Padang dan sediaan daun sirih yang beredar di pasaran, metanol, alkohol 96\%, dietil eter, infusa, Sabouraud Dextrose Agar (SDA), kertas cakram sediaan pabrik dan $\mathrm{NaCl} 90 \%$.

Ekstraksi dilakukan dengan teknik maserasi. Daun gelinggang ditimbang sebanyak $2 \mathrm{~kg}$ kemudiaan dibersihkan ,dicuci dengan air mengalir, dikeringkan, lalu dipotong sampai berbentuk kecil-kecil hingga 200 g. Proses maserasi dilakukan selama 3x24 jam dengan pelarut metanol, alkohol 96\%, dietil eter, dan infusa. Dan dilakukan pengadukan setiap 1x24 jam dengan menggunakan batang pengaduk. disaring menggunakan kain flanel yang memisahkan antara filtrat dan residu, kemudian dipekatkan (kecuali campuran air ledeng) menggunakan destilasi vakum dan dipekatkan lagi menggunakan rotary evaporator.Ekstrak kental dimasukkan ke dalam botol steril.

Penentuan aktivitas antijamur $C$. albicans dilakukan dengan metode apus Kirby-Bauer dengan menggunakan kertas cakram. Metode ini dilakukan dengan prosedur yaitu media agar SDA sebanyak $20 \mathrm{ml}$ dituangkan masing-masing ke dalam 7 buah cawan petri dan dibiarkan hingga padat, setelah itu ditambahkan 0,1 $\mathrm{ml}$ inoculum C. albicans. Permukaan media diapus dengancotton bud hingga tersebar merata. Kertas cakram steril dimasukkan pada botol yang berisi ekstrak daun $C$. alata dengan berbagai taraf konsentrasi dan dibiarkan selama 15 menit. Setelah itu, kertas cakram diletakkan di atas lempeng agar menggunakan pinset. Masing-masing cawan petri ini diinkubasi selama $1 \times 24$ jam pada suhu $37^{\circ} \mathrm{C}$. Zona hambat pertumbuhan di sekeliling kertas cakram menunjukkan uji positif dan diameter zona hambat diukur menggunakan mistar. Jarak kertas saring antara satu dengan yang lainnya sebesar $3 \mathrm{~cm}$ dari tepi media sebesar $2 \mathrm{~cm}$. Skema peletakan kertas saring dapat dilihat pada Gambar 1 (Waluyo, 2007).

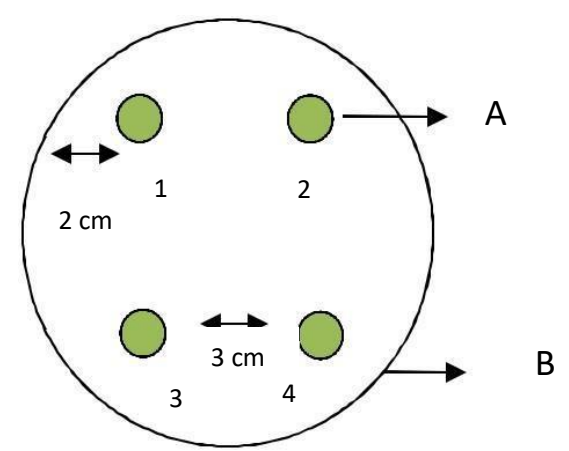

Gambar 1. Peletakkan kertas saring pada media uji, (A) kertas cakram; (B) cawan

$$
\text { petri }
$$

Pengukuran diameter zona hambat dilakukan dengan menggunakan mistar untuk menentukan kekuatan daya hambat ekstrak daun $C$. alata terhadap pertumbuhan jamur C.albicans. Penentuan kategori respon hambatanpertumbuhan dapat dilihat pada Tabel 1 (Ardiansyah, 2005).

Tabel 1. Klasifikasi respon hambatan pertumbuhan jamur

\begin{tabular}{|c|c|}
\hline $\begin{array}{c}\text { Diameter Zona } \\
\text { Bening }\end{array}$ & $\begin{array}{c}\text { Respon Hambatan } \\
\text { Pertumbuhan }\end{array}$ \\
\hline$>2 \mathrm{~cm}$ & Sangat Kuat \\
\hline $1,6-2 \mathrm{~cm}$ & Kuat \\
\hline $1-1,5 \mathrm{~cm}$ & Sedang \\
\hline$<1 \mathrm{~cm}$ & Lemah \\
\hline
\end{tabular}

Data diperoleh melalui pengukuran diameter zona hambat yang ditimbulkan oleh berbagai jenis pelarut. Aktivitas antijamur dianalisis secara statistiaka dengan uji Shapiro Wilk untuk mengetahui normalitas dan homogenitas data. Hasil yang diperoleh adalah data tidak terdistribusi normal, sehingga analisis yang digunakan adalah statistik non parametrik menggunakan uji Kruskall 
Wallis. Untuk mengetahui perbedaan aktivitas antijamur pada setiap pelarut terhadap pertumbuhan jamur $C$. albicans dilakukan uji Mann \& Whitney.

\section{Hasil dan Pembahasan}

Aktivitas antijamur adalah merupakan ukuran kemampuan ekstrak dalam membunuh maupun menghambat pertumbuhan jamur uji. Aktivitas antijamur daun ketepeng cina (C. alata) dan sediaan daun sirih ditunjukkan dengan adanya zona bening atau keruh dimana daerah tersebut tidak ditumbuhi oleh mikroba uji atau sedikit ditumbuhi oleh mikroba uji.
Koloni jamur Candida albicans yang tumbuh pada masing-masing perlakuan menunjukkan adanya perbedaan yang terlihat dari rerata diameter zona hambat setelah inkubasi 24 jam. Berdasarkan rerata zona hambat yang dibandingkan dengan kategori respon hambatan koloninya dapat diketahui bahwa diameter zona hambat tertinggi pada perlakuan dengan SDS 3 dengan nilai rerata sebesar $50,00 \mathrm{~mm}$ dan diameter zona hambat terendah pada perlakuan dengan ekstrak dietil eter dan infusum daun $C$. alata dengan nilai rerata $0 \mathrm{~mm}$ pada Gambar 2 dan Tabel 2.

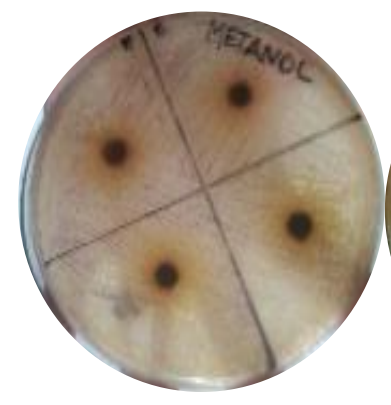

(A)

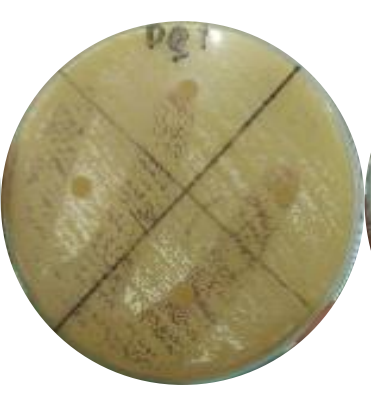

(B)

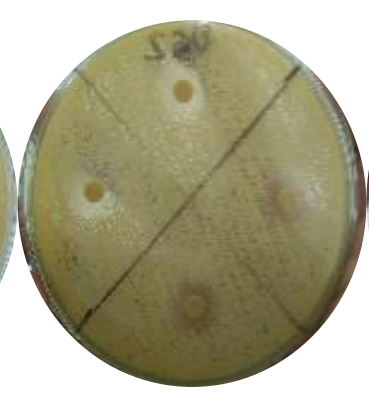

(C)

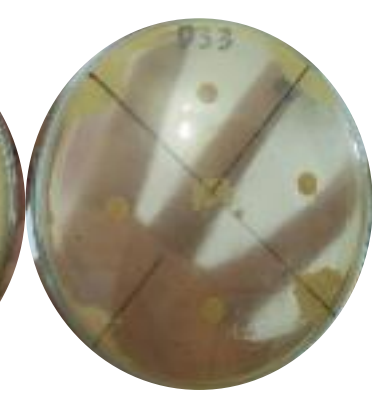

(D)

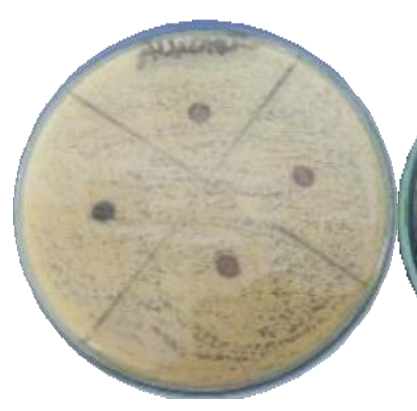

(E)

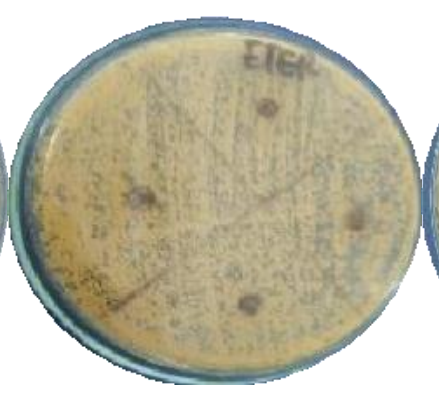

(F)

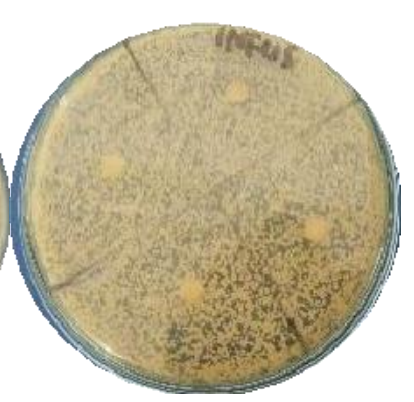

(G)

Gambar 2. Diameter Zona Hambat A) Ekstrak metano, B) $S D S$ 1, C) $S D S$ 2, D) $S D S$ 3, E) Ekstrak alcohol, F) Ekstrak dietil eter, G) Infusa

Uji Kruskall Wallis menunjukkan angka chi-swuare sebesar 24,661 dan probability sebesar $0,000(<0,05)$, sehingga minimal ada satu pasang kelompok yabg berbeda secara bermakna. Untuk mengetahui kelompok yang berbeda secara bermakna, dilanjutkan dengan uji Mann \& Whitney. Hasil uji Mann \& Whitney menunjukkan adanya perbedaan bermakna diantara masing-masing perlakuan. Hasil dapat dilihat pada Tabel 3. 
Tabel 2. Aktivitas daya hambat ekstrak daun C. alata terhadap jamur C. Albicans

\begin{tabular}{|c|c|c|}
\hline Perlakuan & Rerata Zona Hambat ( mm ) & $\begin{array}{c}\text { Respon Hambatan Koloni } \\
\text { Jamur }\end{array}$ \\
\hline Ekstrak Alkohol 96\% & $6,50^{\mathrm{a}}$ & Lemah \\
\hline Ekstrak Dietil Eter & $0^{\mathrm{b}}$ & Lemah \\
\hline Ekstrak Metanol & $13,78^{\mathrm{c}}$ & Sedang \\
\hline Ekstrak Infusum & $0^{\mathrm{d}}$ & Lemah \\
\hline SDS 1 & $11,75^{\mathrm{c}}$ & Sedang \\
\hline SDS 2 & $15,75^{\mathrm{c}}$ & Kuat \\
\hline SDS 3 & $50,00^{\mathrm{e}}$ & Sangat Kuat \\
\hline
\end{tabular}

Keterangan : SDS yaitu sediaan daun sirih. Angka yang ditandai dengan huruf yang sama pada kolom sama memiliki pengaruh yang sama atau nilai yang tidak jauh berbeda pada taraf kepercayaan $95 \%$

Tabel 3. Nilai P uji Mann \& Whitney pada pengukuran daya hambat terhadap C.albicans.

\begin{tabular}{|c|c|c|c|c|c|c|c|}
\hline Perlakuan & $\begin{array}{c}\text { Ekstrak } \\
\text { Alkohol } \\
\mathbf{9 6 \%}\end{array}$ & $\begin{array}{c}\text { Ekstra } \\
\mathbf{k} \\
\text { Dietil } \\
\mathbf{E t e r}\end{array}$ & $\begin{array}{c}\text { Ekstra } \\
\mathbf{k} \\
\text { Metan } \\
\mathbf{~ o l}\end{array}$ & $\begin{array}{c}\text { Ekstra } \\
\mathbf{k} \\
\text { Infusu } \\
\mathbf{m}\end{array}$ & SDS 1 & SDS 2 & SDS 3 \\
\hline $\begin{array}{c}\text { Ekstrak } \\
\text { Alkohol } \\
\mathbf{9 6 \%}\end{array}$ & - & 0,013 & $\begin{array}{c}0,243^{*} \\
*\end{array}$ & 0,013 & 0,019 & 0,017 & 0,013 \\
\hline $\begin{array}{c}\text { Ekstrak } \\
\text { Dietil Eter }\end{array}$ & 0,013 & - & 0,014 & $\begin{array}{c}1,000^{*} \\
*\end{array}$ & 0,013 & 0,011 & 0,008 \\
\hline $\begin{array}{c}\text { Ekstrak } \\
\text { Metanol }\end{array}$ & $0,243^{*}$ & 0,014 & - & 0,014 & $0,245^{*}$ & $0,882^{* *}$ & 0,014 \\
\hline $\begin{array}{c}\text { Ekstrak } \\
\text { Infusum }\end{array}$ & 0,013 & $1,000 *$ & 0,014 & - & 0,013 & 0,011 & 0,008 \\
\hline SDS 1 & 0,019 & 0,013 & $0,245^{*}$ & 0,013 & - & 0,017 & 0,013 \\
\hline SDS 2 & 0,017 & 0,011 & $0,882^{*}$ & 0,011 & 0,017 & - & 0,011 \\
\hline SDS 3 & 0,013 & 0,008 & 0,014 & 0,008 & 0,013 & 0,011 & - \\
\hline Keterangan: & $* * p>0,05$ & & & & & & \\
\hline
\end{tabular}

Berdasarkan Tabel 3 dapat dilihat bahwa nilai $\mathrm{p}$ yang ditunjukkan oleh asymp. Sig yang bermakna $(\mathrm{p}<0,05)$ terhadap beberapa perlakuan. Sementara pada kelompok perlakuan antara ekstrak metanol daun C.alata dan SDS 1, 2 menunjukkan pengaruh yang tidak berbeda nyata dengan nilai (asymp. Sig. $=$ 0,245) pada SDS 1 dan (asymp. Sig. = 0,882) pada SDS 2 dalam menghambat pertumbuhan $C$. albicans. Sehingga dapat dikatakan perlakuan ekstrak metanol daun gelinggang memiliki efektivitas yang hampir sama dengan dua kelompok 
perlakuan SDS yang beredar di pasaran dan dapat menjadi alternatif baru dalam terapi infeksi C.albicans.

Flour albus atau keputihan adalah keluarnya cairan selain darah dari liang vagina di luar kebiasaan, baik berbau maupun tidak berbau dan disertai rasa gatal setempat, dapat terjadi secara fisiologis maupun patologis (Filho et al, 2010). Salah satu cara mengatasi munculnya keputihan adalah dengan membersihkan daerah kewanitaan menggunakan larutan antiseptik seperti povidone iodine. Masyarakat juga umumnya secara tradisional menggunakan daun sirih (Piper betle L) dalam bentuk perasan, infusum, minyak astiri dan ekstrak etanol untuk pembilasan vagina atau vaginal douching.Melihat kemampuan itu banyak produk dalam bentuk sediaan daun sirih (SDS) beredar di pasaran. Selain daun sirih, daun gelinggang juga memiliki efek antijamur.

Di dalam daun gelinggang terkandung senyawa flavonoid dan saponin yang memiliki efek biologis sebagai antifungi (Zhang et al, 2006). Pada uji skrining fitokimia pada daun ketepeng Cina dengan pembuatan serbuk simplisia bahwa mengandung zat aktif senyawa flavonoid, alkaloid, antrakuinon, saponin,dan tanin (Octarya dan Saputra, 2015). Fenol memiliki potensi antijamur karena dapat mendenaturasi ikatan protein pada membran sel sehingga membran sel menjadi lisis dan dapat menembus ke dalam inti sel (Sulistyawati dan Mulyati, 2009).

Pada penelitian ini, terdapat perbedaan daya hambat yang signifikan antara SDS 3 yang beredar di pasaran dengan kelompok ekstrak daun gelinggang terhadap C.albicans sedangkan SDS 1 dan SDS 2 tidak memiliki perbedaan yang signifikan dengan ekstrak daun gelinggang pelarut metanol terhadap C.albicans. Hal ini mungkin terjadi karena SDS memiliki zat kimia yang lebih kuat dibanding dengan ekstrak daun gelinggang.
Berdasarkan penelitian yang telah dilakukan diperoleh hasil pada ekstrak metanol, alkohol 96\%, SDS 1, SDS 2, dan SDS 3 memiliki aktivitas antijamur ditunjukkan dengan adanya zona hambat atau zona bunuh. Sedangkan ekstrak infusum dan dietil eter tidak memiliki aktivitas antijamur karena tidak adanya zona hambat atau zona bunuh yang ditunjukkan oleh perlakuan tersebut. Hal ini kemungkinan karena senyawa-senyawa yang tertarik pada ekstrak infusum dan dietil eter tidak mampu menghambat biosintesis ergosterol. Dimana ergosterol merupakan suatu sterol utama membran sel jamur. Sehingga ketika dihambat akan mengganggu proses transport sehingga makromolekul dan ion-ion dalam sel hilang dan menyebabkan kehancuran yang irreversible.

Perbedaan ini terjadi disebabkan oleh beberapa faktor. Pertama, kepolaran pelarut yang digunakan akan mempengaruhi proses difusi ekstrak kedalam medium SDA. Ekstrak dengan pelarut yang polar akan lebih mudah masuk kedalam media SDA dan proses penghambatan pertumbuhan koloni jamur akan lebih maksimal. Pelarut yang digunakan harus memiliki sifat kepolaritasan yang sama dengan senyawa yang akan ditarik (Sudarmadji et al, 1989). Hal ini diduga karena senyawa metabolit sekunder spesifik yang berperan sebagai antifungi tidak terekstraksi dengan peralut etanol. ${ }^{13}$ Sehingga senyawa metabolit sekunder yang didapat tidak akurat dalam menghambat pertumbuhan jamur C.albicans.Aktivitas antijamur paling besar diantara ekstrak daun gelinggang ditunjukkan oleh ekstrak metanol. Hal ini kemungkinan disebabkan karena semua golongan senyawa tertarik oleh pelarut metanol. Sehingga aktivitas yang dihasilkan lebih besar dibandingkan ekstrak alkohol 96\%, infusum dan dietil eter.

Kedua, kemampuan suatu pelarut untuk mengekstrak senyawa aktif yang berperansebagai anti jamur atau antifungi 
akanmemberikan diameter zona bening yangberbeda. Apabila komponen senyawa aktif yang dapat di ekstrak besar, maka ekstrakmemberikan diameter zona bening yang lebihbesar. Sebaliknya, apabila komponensenyawa aktif yang dapat di ekstrak sedikit,maka diameter zona hambat yang diberikanakan lebih kecil (Octarya, 2015). Ketiga, kemampuan suatu pelarut sebagai antimikroba (Octarya, 2015)

Keempat,umur mikroba, mikroba yang berumur masih muda (stasioner) akan lebih mudah untukmengalami denaturasi protein membran seldan menyebabkan perkembanganpertumbuhan koloni akan lebih kecil.Sedangkan mikroba yang berumur tua(eksponensial) akan lebih rentan terhadapsenyawa lain yang dapat merusak dinding selnya. Kerentanan ini menyebabkan pertumbuhan mikroba tersebut tidak akan terhalang (Octarya, 2015). Selain itu, kemampuan zat antijamur menghambat pertumbuhan jamur dipengaruhi pula oleh beberapa faktor antara lain : konsentrasi zat antifungi, jenis, jumlah, umur, dan keadaan jamur, suhu, waktu kontak, sifatsifat kimia dan fisik media pertumbuhan, seperti $\mathrm{pH}$, kadar air, nutrisi, serta jumlah komponen di dalamnya (Fardiaz et al, 1992).

Pada penelitian serupa aktivitas antijamur ekstrak daun ketepeng cina sangat baik pada konsentrasi rendah telah memberikan zona bunuh yang besar. Pada konsentrasi 5\% terjadi aktivitas antijamur yang paling besar, merupakan konsentrasi efektif dari ekstrak metanol dan fraksi daun ketepeng cina yaitu konsentrasi yang memberikan aktivitas antijamur dengan zona bunuh terbesar karena dapat berdifusi dengan baik kedalam media agar. Pada konsentrasi $7 \%$ dan $9 \%$ aktivitas antijamur mengalami penurunan. Penurunan aktivitas antijamur ini disebabkan karena konsentrasi ekstrak yang cukup besar sehingga viskositas menjadi tinggi dan menyebabkan ekstrak tidak mampu berdifusi dengan baik ke dalam media agar, sehingga menunjukkan penurunan aktivitas antijamur. Dengan penggunaan konsentrasi $100 \%$ pada penelitian ini kemungkinan dapat menurunkan efektifitas daun gelinggang dalam menghambat pertumbuhan C.albicans (Triana et al, 2016).

\section{Kesimpulan}

Berdasarkan hasil dan analisis data, dapat disimpulkan kelompok perlakuan dengan SDS 3 memiliki respon hambtan koloni jamur tertinggi. Kelompok dengan respon hambat terendah adalah kelompok perlakuan dengan ekstrak alkohol 96\% daun gelinggang. Pada kelompok perlakuan ekstrak dietil eter dan infusum daun gelinggang tidak dapat menghambat pertumbuhan jamur $C$. albicans. Perbedaan hasil ini dapat disebabkan oleh sifat kelarutan zat aktif pada ekstrak dan perbedaan kecepatan difusi pada media agar.

Pada kelompok perlakuan ekstrak metanol daun C.alata dan sediaan daun sirih (SDS ) 1 dan 2 menunjukkan pengaruh yangtidak berbeda nyata dengan nilai (asymp. Sig. $=0,245$ ) pada SDS 1 dan (asymp. Sig. $=0,882)$ pada SDS 2 dalam menghambat pertumbuhan jamur C.albicans, sehingga dapat dikatakan perlakuan ekstrak metanol daun gelinggang memiliki efektifitas yang hampir sama dengan 2 kelompok perlakuan sediaan daun sirih yang beredar di pasaran dan dapat menjadi alternatif terbaru dalam terapi infeksi C.albicans. 


\section{Daftar Pustaka}

Zubier F, Bramono K, Widaty S, Nilasari $\mathrm{H}$, LouisaM, Rosana Y. Efikasi sabun ekstrak sirih merah dalam mengurangi gejala keputihan fisiologis. Majalah Kedokteran Indonesia. 2010; 60(1).

Hawkins, Bourne. Text book of gynaecology. Edisi ke-15. USA: Elsevier Publication; 2011.

Berek JS, Berek, Novak. Gynecology. Edisi ke-14. USA: Lippincott Williams \& Wilkins Publishers; 2007. Wijayanti RE, Hardjito K, Yuliati S. Gambaran cara-cara penanganan keputihan yang dilakukan oleh remaja putri usia 16-18 tahun di MAN 3 Kediri. Jurnal Penelitian Kesehatan Suara Forikes. Ponorogo. 2011;II(4).

Syamsuhidayat, S. dan Ria,J.1991. Inventarisasi Tanaman Obat Indonesia. Jakarta : Mogeraw Hill. Inc Waluyo, L 2007, Mikrobiologi Umum, Edisi Revisi,UPT, Penerbit:

Universitas Muhammadiyah. Malang Ardiansyah. 2005 . Antimikroba dari Tumbuhan. (Bagian kedua) Available from ; http://www.beritaiptek.com diakses pada tanggal 15 Juli 2018).

Filho CSD, Diniz CG, Silvia VL. Bacterial vaginosis: clinical, epidemiologic, and microbiological features. Revista Juiz de For a. 2010 (diunduh 15 Juli 2018). Tersedia dari: URL: HYPERLINK

http://www.epirev.oxfordjournals.org /content/24/2/102.full

Zhang, Y.S., H.Y. Yi, and H.F tang. 2006. Cutotoxic sulfated triterpene glycosides from the sea cucumber Pseudocolochirus violaceus. Chemistry \& Biodiversity. 3(2):807817.

Octarya, Z., Dan R. Saputra. 2015. Pengaruh Jenis Pelarut Terhadap Jumlah Ekstrak dan Daya Antifungi Daun Ketepeng Cina (Cassia alata) terhadap Jamur Trychophyton sp. Jurnal Photon. Vol 5. No 2.
Sulistyawati, D., dan S. Mulyati. 2009. Uji aktivitas infusa daun jambu mete (Anacardium occidentale L.) terhadap Candida albicans. Biomedika.; 2(1): 47-51.

Sudarmadji, S., Haryono., B, Suhardi. Analisis untuk bahan makanan dan pertanian. Yogyakarta: Liberty; 1989.

Fardiaz D., N. Andarwulan, dan N.I Puspitasari. 1992. Teknis Analisis Sifat Kimia dan Fungsional Komponen Pangan. PAU Pangan dan Gizi, IPB. Bogor

Triana O, Prasetya F, Kuncoro H, Rijai L. 2016. Aktivitas Antijamur Ekstrak Daun Ketepeng Cina (cassia alata 1.). Jurnal Sains dan Kesehatan. Vol 1. No 6. 